\title{
Komposisi Jenis Juvenil Ikan di Perairan Ekosistem Mangrove Pulau Parang Kepulauan Karimunjawa Kabupaten Jepara
}

\section{Composition of Juvenil Fish in Mangrove Waters, Parang Island, Karimunjawa Island, Jepara District}

\author{
Maharani*1 $^{*}$, Mujiyanto ${ }^{2}$, Riska $^{3}$ dan La Ode Abdul Fajar Hasidu ${ }^{4}$ \\ ${ }^{1,3,4}$ Universitas Sembilanbelas November Kolaka, Sulawesi Tenggara 93561, Indonesia. \\ ${ }^{2}$ Balai Riset Pemulihan Sumber Daya Ikan Jatiluhur, Purwakarta, Indonesia.
}

Korespondensi : maharanijafar2@gmail.com

\begin{abstract}
ABSTRAK
Ekosistem mangrove merupakan sumberdaya alam hayati yang memiliki manfaat aspek ekologi yaitu sebagai tempat hidup beragam jenis biota perairan. Salah satu jenis biota ekonomis penting yang hidup di daerah mangrove yaitu komunitas ikan. Penelitian dilaksanakan pada bulan Desember 2012 (musim barat). Penelitian ini bertujuan untukmengkaji komposisi jenis juvenil ikan di perairan ekosistem mangrove Pulau Parang Kepulauan Karimunjawa.Juvenil ikan dikoleksi dengan jaring angkat (lift net), jaring lempar ukuran mata jaring 2 inchi, alat pancing serta serok (seser) ikan.Komposisi jenis juvenil ikan di perairan ekosistem mangrove Pulau Parang yang dikoleksi pada musim barat yaitu berjumlah 10 jenis dari 9 genus dan 9 famili.Lutjanidae merupakan famili ikan yang memiliki nilai ekonomis penting.Nilai keanekaragaman jenis pada ketiga lokasi menunjukkan sebaran yang relatif merata, dimana penyebaran individu tiap jenis relatif seragam dan tidak ada spesies yang mendominasi. Indeks keanekaragaman $(H)$ jenis juvenil ikan berkisar antara 1,252 - 1,328; indeks keseragaman (E) berkisar antara 0,668 - 0,825 dan indeks dominansi (C) berkisar antara $0,292-0,355$.
\end{abstract}

Kata kunci : Komposisi, juvenil, mangrove, Kepulauan Karimunjawa

\begin{abstract}
Mangrove ecosystems are biological natural resources that have benefits from ecological aspects, namely as a place to live for various types of aquatic biota. One type of economically important biota that lives in mangrove areas is the fish community. The research was conducted in December 2012 (west season). This study aims to examine the composition of juvenile fish species in the waters of the mangrove ecosystem of Parang Island, Karimunjawa Islands. Juvenile fish are collected using lift nets, throwing nets 2 inches in size, fishing rods and fish scoops. The juvenile species composition of fish in The waters of the Parang Island mangrove ecosystem were collected in the western season, totaling 10 species from 9 genera and 9 families. Lutjanidae is a family of fish that has important economic value. The value of species diversity at the three locations shows a relatively even distribution, where the distribution of individuals for each species is relatively uniform and no species dominates. Diversity index $(H)$ of juvenile fish ranged from 1.252 to 1.328 ; The uniformity index (E) ranges from $0.668-0.825$ and the dominance index $(\mathrm{C})$ ranges from $0.292-0.355$.
\end{abstract}

Keywords : Composition, juvenile, mangrove, Karimunjawa Islands 


\section{PENDAHULUAN}

Ekosistem mangrove merupakan salah satu ekosistem hutan tropis yang memiliki karakteristik yang khas dan juga merupakan salah satu ekosistem penting di daerah pesisir/ pantai.Keberadaan Ekosistem mangrove merupakan ekosistem yang tak kalah pentingnya, selain menyediakan hutan pantai yang sangat kokoh.Mangrove juga, merupakan mata rantai penting dalam pemeliharaan keseimbangan siklus biologi di suatu perairan.Hal inilah yang menjadikan ekosistem mangrove dijadikan sebagai tempat mencari makan, tempat asuhan dan tempat perlindungan berbagai jenis hewan akuatik yang mempunyai nilai ekonomis penting termasuk ikan.

Kajian mengenai potensi dan komposisi sumberdaya ikan perlu dilakukan karena sangat berguna untuk mengetahui kekayaan sumberdaya ikan yang juga dapat digunakan sebagai masukan dalam kebijakan pengelolaan kawasan ekosistem. Ekosistem mangrove di Pulau Parang masih dalam keadaan baik, namun tidak menutup kemungkinan karena kenaikan jumlah penduduk akan berdampak pada pemanfaatan ekosistem mangrove yang tidak terkendali. Dan keadaan ini akan mengurangi fungsi ekosistem mangrove dalam menunjang kehidupan biota air yang memanfaatkan keberadaan ekosistem mangrove tersebut sebagai tempat pemeliharaan anakan, pembesaran dan sebagai tempat mencari makan.

Pentingnya keberadaan ekosistem mangrove untuk kelangsungan proses ekologis, hidrologis dan ketersediaan komunitas ikan, maka perlu dilakukan penelitian ini dengan mengkaji komposisi dan keanekaragaman jenis juvenil ikan di perairan ekosistem mangrove Pulau Parang Kepulauan Karimunjawa.

\section{METODE PENELITIAN}

\section{Waktu dan Tempat Penelitian}

Penelitian ini dilaksanakan pada bulan Desember 2012. Lokasi penelitian bertempat di kawasan Perairan Ekosistem Mangrove Pulau Parang Kepulauan Karimunjawa, Kabupaten Jepara, Jawa Tengah. 


\section{Penentuan Lokasi Penelitian}

Lokasi penelitian dibagi atas tiga stasiun/ lokasi pengamatan (Gambar 1). Penentuan titik stasiun dilakukan pada setiap zona pemanfaatan lokasi secara horizontal dan berdasarkan keberadaan ekosistem mangrove yang dianggap dapat mewakili areal mangrove di perairan ekosistem mangrove Pulau Parang Kepulauan Karimunjawa, yaitu:

a. Stasiun I

Stasiun I ditempatkan di sebelah Barat kawasan Pulau Parang yaitu daerah teluk Legon Boyo yang merupakan zona pemanfaatan perikanan tradisional.Kondisi topografi pantainya substrat berlumpur.Terdapat beragam jenis tumbuhan mangrove, semak dan tanaman pantai lainnya.

b. Stasiun II

Stasiun II ditempatkan di sebelah Timur kawasan Pulau Parang yaitu Watu Merah yang merupakan zona pemanfaatan perikanan.Kondisi topografi pantainya relatif landai dengan substrat pasir berlumpur dan berbatu.Terdapat vegetasi mangrove, semak dan perkebunan kelapa.

c. Stasiun III

Stasiun III ditempatkan di sebelah selatan Pulau Parang yaitu Ujung Bengkok.Areal ini tidak berpenduduk dan memiliki areal ekosistem mangrove yang sangat sempit/ sedikit.Perairan di lokasi ini terbagi dalam zona pemanfaatan pariwisata.Pantai memiliki kontur landai dengan substrat pasir putih. Vegetasi berupa semak, pohon kelapa, mangrove asosiasi serta vegetasi pantai lain. Titik sampling berada di sebelah barat pulau yang menghadap ke laut lepas. Jarak antara padang lamun dan rataan terumbu relatif jauh dan terpisahkan oleh pasir dan pecahan karang. 


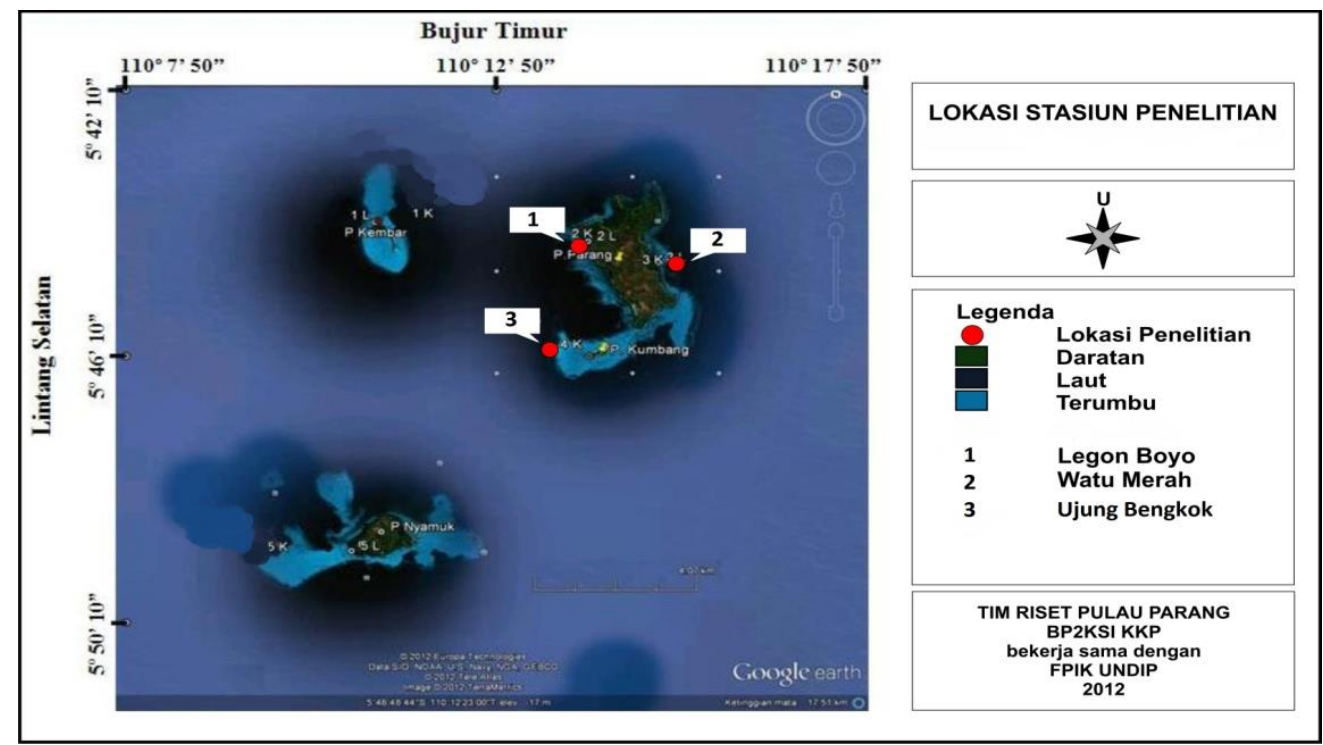

Gambar 1. Peta lokasi penelitian

\section{Pengambilan Sampel}

Sampel juvenil ikan di perairan ekosistem mangrove, dikoleksi menggunakan jaring dengan ukuran mata jaring $500 \mu$ (Romimohtarto, 2001).Jaring dioperasikan menggunakan sistem lift net (Redjeki dan Pribadi, 2009). Sementara pemasangan jaring dilakukan dengan cara ditempatkan $\pm 50 \mathrm{~cm}$ di bawah permukaan air. Selain menggunakan jaring sistem lift net, juga menggunakan jaring lempar ukuran mata jaring 2 inchi, dan alat pancing dengan mata pancing kecil $( \pm 1 \mathrm{~cm})$ dan besar $( \pm 2 \mathrm{~cm})$ serta serok (seser) ikan.

Specimen juvenil ikan yang diperoleh dihitung jenis dan jumlah individu pada tiap jenisnya, kemudian difiksasi menggunakan formalin 10\% (Nontji, 2008).Setelah itu, sampel kemudian diidentifikasi dan dianalisis menggunakan buku identifikasi (Kuiter, 2001) di Laboratorium Balai Penelitian Pemulihan dan Konservasi Sumberdaya Ikan (BP2KSI) Purwakarta, Jawa Barat.

\section{Parameter Fisika dan Kimia Lingkungan Perairan}

Parameter perairan yang diperoleh dari masing-masing stasiun penelitian terdiri atas: parameter fisika dan kimia. Parameter fisika dan kimia perairan yang diambil yaitu suhu air, salinitas, pH, DO,kecerahan, Nitrat, Nitrit, Amonium, Orthoposfat dan BOT air. 


\section{Analisis data}

Struktur komunitas juvenil ikan meliputi: komposisi, indeks keanekaragaman, Dominasi dan indeks keseragaman jenis juvenil di Perairan Ekosistem Mangrove bagian Barat Kepulauan Karimunjawa. Sampel yang telah diidentifikasi, dihitung jumlah total setiap jenis dan untuk mengetahui persentase jenis ikan ditentukan berdasarkan rumus Odum (1996) yaitu :

Keterangan :

$$
P=\frac{n i}{N} x 100 \%
$$

$\mathrm{P} \quad=$ Persentase setiap jenis

ni $=$ Jumlah individu jenis ikan $k e-i$

$\mathrm{N}=$ Jumlah total individu setiap jenis

Indeks keanekaragaman Juvenil Ikan dihitung menggunakan Indeks ShannonWiener (Odum, 1993):

$$
H^{\prime}=-\sum_{i=1}^{n}\left(\frac{n i}{N} \log \frac{n i}{N}\right)
$$

Keterangan :

H' : Indeks Keanekaragaman Shannon-Wiener

ni : Jumlah individu spesies ke-i

$\mathrm{N} \quad$ : Jumlah total individu

Indeks keseragaman juvenil ikan dihitung menggunakan rumus, menurut Odum (1993) sebagai berikut:

$$
\mathrm{E}=\mathrm{H}^{\prime} / \mathrm{H}^{\prime} \text { maks }
$$

Keterangan:

E : Indeks Keseragaman spesies

H' : Indeks Keanekaragaman Shannon-Wiener

S : Jumlah spesies 
Indeks dominasi jenis juvenil ikan dihitung dengan menggunakan. Indek Dominasi Simpson (Odum, 1993) :

$$
\mathrm{C}=2 \sum_{i=1}^{n}(n i / N)
$$

Keterangan :

C : Indeks Dominasi

ni : Jumlah individu spesies ke-I

$\mathrm{N} \quad$ : Jumlah total Individu

\section{HASIL DAN PEMBAHASAN}

\section{Parameter Fisika Kimia Perairan Ekosistem Mangrove}

Parameter perairan yang diperoleh dari masing-masing lokasi penelitian terdiri atas: parameter fisika dan kimia (Tabel 1), sebagai berikut:

Tabel 1. Nilai Parameter Perairan Ekosistem Mangrove Pulau Parang Kepulauan Karimunjawa

\begin{tabular}{clcccc}
\hline No. & Parameter & Satuan & \multicolumn{3}{c}{ Lokasi Penelitian } \\
& & & Legon Boyo & Watu Merah & Ujung Bengkok \\
\hline 1 & Suhu Air & ${ }^{\circ} \mathrm{C}$ & 29,47 & 30,12 & 29,96 \\
2 & Salinitas & $\%$ o & 33,15 & 32,08 & 32,00 \\
3 & pH & & 7,60 & 7,78 & 7,86 \\
4 & DO & $\mathrm{mg} / 1$ & 5,26 & 3,40 & 6,81 \\
5 & Kecerahan & $\mathrm{m}$ & 0,35 & 0,24 & 0,38 \\
6 & Nitrat & $\mathrm{mg} / 1$ & 0,15 & 0,18 & 0,11 \\
7 & Nitrit & $\mathrm{mg} / 1$ & 0,02 & 0,01 & 0,01 \\
8 & Amonium & $\mathrm{mg} / 1$ & 0,30 & 0,19 & 0,11 \\
9 & Orthoposfat & $\mathrm{mg} / 1$ & 0,02 & 0,02 & 0,02 \\
10 & BOT Air & & 5,65 & 6,85 & 5,21 \\
\hline
\end{tabular}

\section{Komposisi Juvenil Ikan}

Jenis-jenis juvenil ikan yang ditemukan di Perairan Ekosistem Mangrove Pulau Parang Kepulauan Karimunjawa pada bulan Desember (musim Barat) berjumlah 10 jenis, yang tergolong ke dalam 8 famili dan 9 genus. Secara keseluruhan hasil tersebut 
menunjukkan bahwa keragaman ikan di Pulau Parang Kepulauan Karimunjawa termasuk cukup tinggi bila dibandingkan dengan hasil penelitian dari Sungai Ciporeang di Cagar Alam Leuweung Sancang, yang hanya memperoleh 6 jenis ikan (Dewantorodkk., 2005). Sedangkan penelitian yang dilakukan Djamali (1995) berhasil mengkoleksi 15 jenis ikan di perairan mangrove Sungai Donan dan Sungai Sapuregel, Cilacap.Jumlah jenis juvenil ikan yang berhasil ditangkap di Pulau Parang Kepulauan Karimunjawa cukup tinggi, dikarenakan kondisi mangrovenya relatif baik, meskipun ada beberapa stasiun/ pulau yang berpenghuni, yaitu Legon Boyo.Perairan Legon Boyo yang terletak di sebelah Barat Pulau Parang termasuk dalam zona pemanfaatan perikanan tradisional. Lokasinya berada di Utara dermaga pulau dan berdasarkan pengamatan di lapangan lokasi ini termasuk kawasan yang sering dilalui kapal nelayan dan Watu Merah terletak di sisi timur Pulau Parang (BTN Karimunjawa, 2012 dalam Kaimuddin, 2012).

Keberadaan mangrove mampu menopang fauna akuatik yang hidup dan berasosiasi di dalamnya (Dorenbosch dalam Genisa, 2006). Sama halnya di area Segara Anakan yang juga terjadi eksploitasi besar-besaran, antara lain banyak hutan mangrove yang dikonversi menjadi tambak-tambak perikanan dan pemukiman, ditambah adanya pendangkalan akibat lumpur dari longsoran beberapa sungai di sekitarnya (Mulyadi $d k k$., 2009; Supriyanto, 2009). Secara tidak langsung kondisi tersebut berkaitan dengan peranan mangrove yang merupakan habitat dari beraneka ragam fauna akuatik.Sejalan dengan itu Genisa (2006) bependapat bahwa tinggi rendahnya keanekaragaman jenis dipengaruhi oleh banyak faktor, salah satunya adalah kualitas lingkungan.

Famili yang berhasil ditemukan adalah dari Apogonidae, Atherinidae, Gobiidae, Hemiramphidae, Lutjanidae, Siganidae, Sphyraenidae dan Terapontidae.Jenis dari Apogon ceramensis, Sphaeramia orbicularisdan Zenarchopterus gili banyak ditemukan di Legon Boyo. Sedangkan di lokasiWatu Merah dari jenis A. ceramensis, Atherinomorus lacunosus dan Z. dispar dan di lokasi Ujung Bengkok jenis yang paling banyak ditemukan adalah A. ceramensis, S. orbicularis dan Terapon theraps. Komposisi jenis ikan yang ditemukan pada masing-masing lokasi penelitian secara lengkap disajikan pada Tabel 2 berikut: 
Tabel 2. Komposisi Jenis ikan yang ditemukan di Perairan Ekosistem Magrove Pulau Parang Kepulauan Karimunjawa

\begin{tabular}{cllccc}
\hline No & Famili & \multicolumn{1}{c}{ Spesies } & $\begin{array}{c}\text { Lokasi Penelitian } \\
\text { Legon } \\
\text { Boyo }\end{array}$ & $\begin{array}{c}\text { Watu } \\
\text { Merah }\end{array}$ & $\begin{array}{c}\text { Ujung } \\
\text { Bengkok }\end{array}$ \\
\hline 1 & Apogonidae & $\begin{array}{l}\text { Apogon ceramensis } \\
\text { Sphaeramia } \\
\text { orbicularis }\end{array}$ & 41 & 126 & 35 \\
& & 64 & 11 & 23 \\
2 & Atherinomorus & & & 6 \\
3 & Gobiidae & $\begin{array}{l}\text { Ctenonogobius } \\
\text { perspicillatus }\end{array}$ & 2 & 3 & 0 \\
4 & Lutjanidae & Lutjanus goldiei & 0 & 5 & 0 \\
5 & Siganidae & Siganus punctatus & 0 & 3 & 0 \\
6 & Sphyraenidae & Sphyraena barracuda & 6 & 0 & 0 \\
7 & Terapontidae & Terapon theraps & 0 & 0 & 30 \\
& Hemiramphid & Zenarchopterus dispar & 0 & 44 & 0 \\
\hline & ae & Zenarchopterus gili & 18 & 0 & 2 \\
\hline & \multicolumn{2}{c}{ Total } & 133 & 238 & 96 \\
\hline
\end{tabular}

Persentase komposisi jenis juvenil ikan yang ditemukan di semua lokasi penelitian secara lengkap disajikan pada Gambar 2 hingga Gambar 4 berikut:

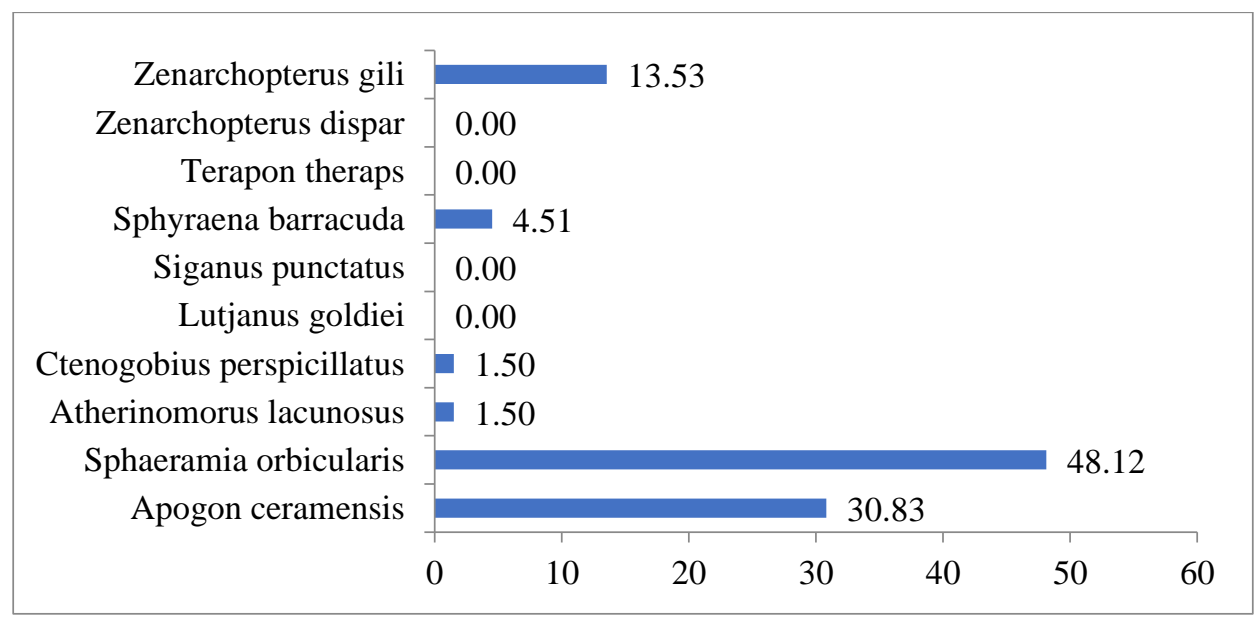

Gambar 2. Persentase Komposisi Jenis Juvenil Ikan di Legon Boyo (\%) 


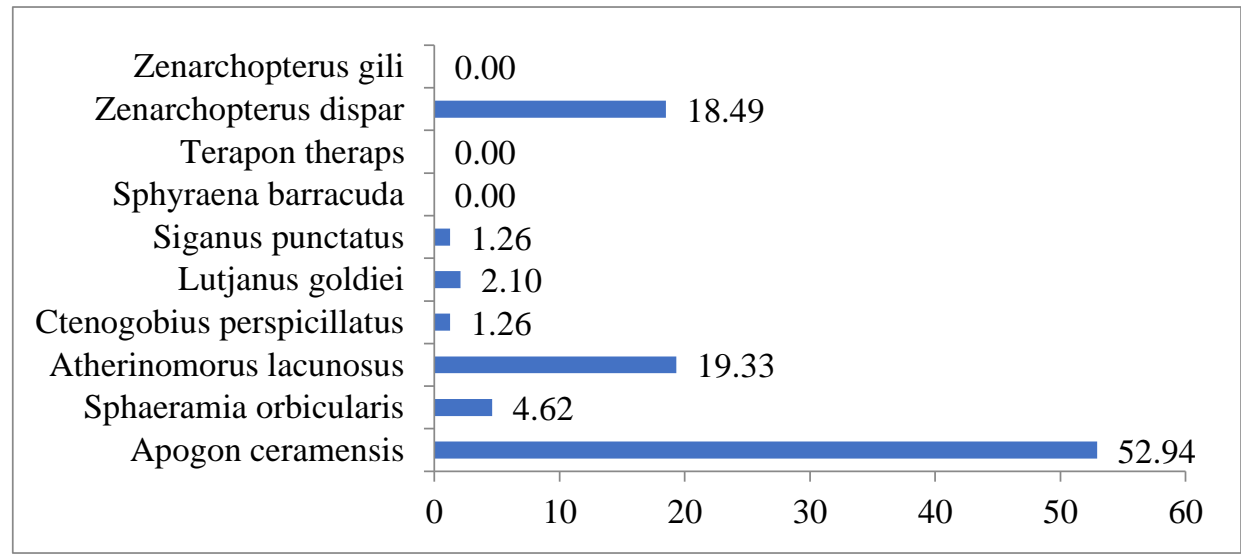

Gambar 3. Persentase Komposisi Jenis Juvenil Ikan di Watu Merah (\%)

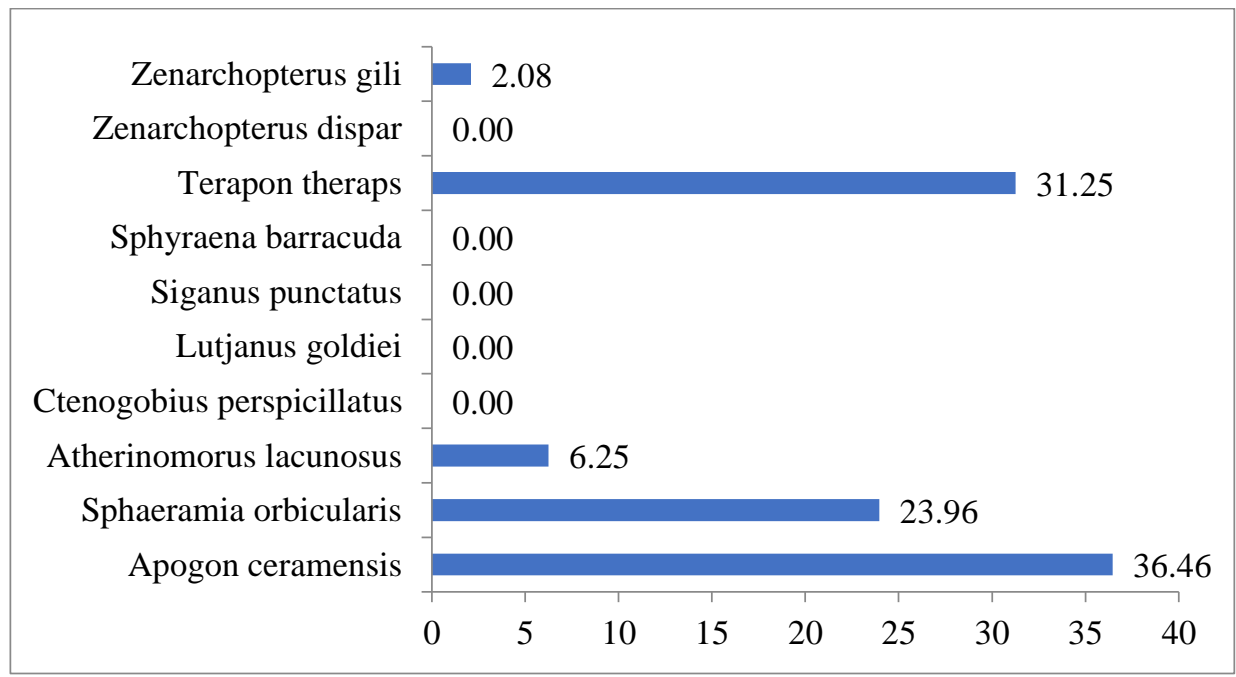

Gambar 4. Persentase Komposisi Jenis Juvenil Ikan di Ujung Bengkok (\%)

Dari 8 famili yang diperoleh, Apogonidae merupakan famili yang memiliki anggota jenis tertinggi, kemudian Atherinidae, Hemiramphidae dan Terapontidae. Komposisi jenis juvenil ikan tertinggi pada jenis A.ceramensisdan S. orbicularisdari famili Apogonidae yang ditemukan paling banyak masing-masing di Watu Merah sebanyak 52,94\% (Gambar 3) dan di Legon Boyo sebanyak 48,12\% (Gambar 2). Jenis $S$. orbicularis ditemukan berenang secara berkelompok. Penelitian dari Adrim et al (1984) juga menemukan hal sama di Pulau Pari yang didominasi oleh ikan S. orbicularis dengan jumlah 133 ekor yang merupakan kelompok dari Apogon. Komposisi jenistertinggi 
berikutnya pada jenis A. lacunosusdari famili Atherinidae yang ditemukan paling banyak di Watu Merah sebanyak 19,33\% (Gambar 3). Banyaknya komposisi A. lacunosus diduga karena jenis ini merupakan ikan-ikan yang sifatnya bergerombol dapat hidup pada perairan pantai dan padang lamun (Matsuura $d k k ., 2000$ ).

Jenis dari famili Hemiramphidae baik Z. gili ataupun Z. dispar ditemukan di seluruh lokasi pengambilan sampel juvenil ikan (Gambar 2, 3 dan 4). Hal ini karena Hemiramphidae memiliki kemampuan adaptasi yang baik pada kawasan perairan mangrove.Sifat dari ikan ini (titi-titi disebut oleh nelayan lokal) yaitu berada $5-10 \mathrm{~cm}$ di bawah permukaan air di area mangrove, lebih terlihat berenang pada daerah permukaan perairan.Bercirikan tipis memanjang serta mempunyai mulut yang panjang sehingga pergerakannya sangat lincah. Jenis ikan dari famili ini menjadikan mangrove sebagai tempat hidupnya karena hanya ditemukan pada ukuran juvenil, berlindung serta bergerombol di bawah perakaran mangrove. Hal ini sesuai dengan pendapat Kuiter (2001) yang menyatakan bahwa ikan Z. gilli merupakan ikan yang berpenghuni di area mangrove dan aliran sungai serta ukuran panjangnya hanya mencapai $17 \mathrm{~cm}$.

Demikian pula dengan jenis dari family Gobiidae jugaditemukan di Legon Boyo dan Watu Merah (Gambar 2 dan 3).Ciri khusus dari jenis ini yaitu sirip perutnya bersatu dan berbentuk seperti piringan pencengkram yang berfungsi untuk melekatkan dirinya pada substrat, terlihat mendiami dasar perairan dan terkadang berada diantara bebatuan.Pramudji (2008) menyatakan bahwa di kawasan pesisir Delta Mahakam ditemukan ikan dari family Gobiidae dalam stadium larva dan juvenil. Beberapa ikan gobi juga diketahui merupakan penghuni tetap kawasan mangrove, diantaranya adalah jenis ikan gelodok Periopthalmus argentilineatus dan P. kalolo. Ikan gelodok dikenal dengan nama mudskipper yang dapat hidup di air dan permukaan lumpur di sekitar mangrove dan memiliki kemampuan berjalan dan memanjat dengan menggunakan sirip dadanya. Bila dalam keadaan bahaya, ikan gelodok akan bersembunyi di sekitar tanaman mangrove.

Chong et al (1990) berpendapat bahwa komunitas ikan di perairan mangrove didominasi oleh beberapa jenis ikan, meskipun jenis ikan yang tertangkap relatif banyak.Seluruh jenis ikan yang tertangkap di lokasi penelitian relatif berukuran juvenil.Walaupun tampak beberapa nelayan menjaring di sekitar Sungai Cikawung 
namun ikan hasil perolehannya belum dapat dikatakan dewasa, hanya berukuran remaja (Wahyudewantoro, 2009). Hal tersebut sejalan dengan pendapat Odum (1971) yang menyatakan bahwa ekosistem mangrove dikenal sebagai daerah asuhan nursery dan feedingground, didukung pula oleh hasil penelitian di hutan mangrove Bahama yang kebanyakan sampel ikan yang diperoleh berukuran juvenil(Wilcox et al, 1975).

\section{Struktur komunitas juvenil ikan}

Struktur komunitas juvenil ikan, meliputi: Keanekaragaman, Dominasi dan Keseragaman jenis juvenil di Perairan Ekosistem Mangrove Pulau Parang Kepulauan Karimunjawa disajikan pada Tabel 3. berikut:

Tabel 3. Nilai Indeks Keanekaragaman (H), Indeks Dominasi (C) dan Indeks Keseragaman (E) Juvenil Ikan di Perairan Ekosistem Mangrove Pulau Parang Kepulauan Karimunjawa

\begin{tabular}{cccc}
\hline Indeks & Legon Boyo & Watu Merah & Ujung Bengkok \\
\hline H & 1.252 & 1.300 & 1.328 \\
C & 0.347 & 0.355 & 0.292 \\
E & 0.698 & 0.668 & 0.825 \\
\hline
\end{tabular}

Nilai indeks keanekaragaman jenis berkisar antara 1,252 - 1,328, nilai yang tertinggi berada di Ujung Bengkok dan yang terendah berada di Legon Boyo (Tabel 3). Data yang ada memperlihatkan penyebaran jumlah dan jenis komunitas juvenil pada ketiga lokasi penelitian tersebut tidak jauh berbeda. Penggolongan keanekaragaman jenis pada komunitas juvenil ini berdasarkan kriteria yang digunakan Shannon - Wienner (Soegianto, 1994). Yang menyatakan bahwa keanekaragaman jenis termasuk dalam kategori sedang jika $\mathrm{H}^{\prime}$ berada pada nilai $1 \leq \mathrm{H}^{\prime} \leq 3$. Nilai keanekaragaman di Ujung Bengkok lebih tinggi dari lokasi penelitian lainnya dengan jumlah juvenil ikan tangkapan yaitu sebanyak 96 individu. Kondisi tersebut dikarenakan Pulau Nyamuk mempunyai variasi habitat (substrat) yang baik.Substrat dasarnya berupa lumpur dan sedikit berpasir. Gunarto (2004) berpendapat bahwa daerah atau substrat lumpur merupakan habitat berbagai nekton, yang menandakan daerah tersebut kaya akan sumber pakan. Adanya variasi habitat (substrat) seperti kondisi fisik dan lingkungan sekitar 
mempengaruhi keragaman jenis-jenis ikan (McManus et al., 1981; Yustina, 2001). Selain itu, karakteristik Watu Merah memiliki percabangan, anak sungai berkelok-kelok dan banyak ditumbuhi semak diduga kondisi tersebut sangat mendukung kehidupan ikan.

Nilai Indeks Dominasi jenis juvenil ikan berkisar antara 0,292-0,355, nilai yang tertinggi ditemukan di Watu Merah dan terendah di Ujung Bengkok (Tabel 3).Dari data tersebut menunjukkan bahwa dominansi jenis juvenil ikan di Watu Merah tergolong dominasi rendah. Hal ini disebabkan oleh kondisi komunitas yang mendekati stabil sehingga tidak ada jenis tertentu dalam komunitas juvenil ikan yang mendominasi secara mencolok.Fakta ini seiiring dengan nilai indeks keanekaragamannya yang tinggi di antara semua stasiun yaitu 1,328 (kategori sedang).

Nilai Indeks Keseragaman jenis komunitas juvenil ikan berkisar antara 0,668 - 0,825, nilai yang tertinggi ditemukan di Ujung Bengkok dan terendah ditemukan di Watu Merah (Tabel 3). Nilai keseragaman jenis yang diperoleh di semua lokasi penelitian menunjukkan bahwa keseragaman jenis juvenil kategori tinggi.Nilai indeks keseragaman yang tinggi di ujung Bengkok seiring dengan nilai indeks keanekaragamannya yang berada pada kategori sedang.Komunitas yang stabil menunjukkan bahwa penyebaran jumlah individu umumnya seragam, walaupun ada jenis tertentu yang dapat mendominasi komunitas juvenil tersebut, namun dominasinya tidak begitu mencolok.Hal ini didukung oleh Ludwig dan Reynolds (1988) bahwa keseragaman jenis suatu komunitas ditentukan oleh kekayaan jenis dan kemerataan jenis.Indeks kemerataan menjadi tinggi, apabila tidak terjadi pemusatan individu pada suatu jenis tertentu (Odum, 1971).

Perbedaan struktur komunitas juvenil ikan antar lokasi penelitian disebabkan karena perbedaan kondisi perairan secara tidak langsung mempengaruhi karakteristik habitat ikan tersebut.

\section{KESIMPULAN DAN SARAN}

\section{Kesimpulan}

Pada ketiga stasiun/ lokasi penelitian, yaitu: Legon Boyo, Watu Merah dan Ujung Bengkok diperoleh 10 jenis juvenil ikan yang tergolong ke dalam 8 famili, 9 genus dengan jumlah juvenil yang berhasil ditangkap sebanyak 467 individu juvenil ikan. 
Apogonidae merupakan famili yang memiliki anggota jenis terbesar/ dominan dan terdapat jenis ikan Zenarchopterus dispar dan Z. gili yang merupakan penghuni tetap kawasan mangrove. Jenis dengan jumlah individu tertinggi adalah Apogon ceramensis.

\section{Saran}

Perlu dilakukan penelitian lanjutan mengenai kajian struktur komunitas ikan di bagian Timur Kepulauan Karimunjawa sebagai bahan pembanding dan pelengkap data/ khasanah pengetahuan sumber daya ikan di kawasan Kepulauan Karimunjawa sebagai Taman Nasional yang sangat perlu pengawasan dan pengembangan dalam bidang perikanan.

\section{UCAPAN TERIMA KASIH}

Penulis mengucapkan Terima Kasih kepada : (1) Balai Penelitian Pemulihan Dan Konservasi Sumberdaya Ikan (BP2KSI) yang saat ini berubah nama menjadi BRPSDI (Balai Riset Pemulihan Sumber Daya Ikan) bersama P4KSI BALITBANG KP. Penelitian ini adalah salah satu keluaran dari hasil kegiatan riset "Pengkajian Ekosistem Sumberdaya Ikan di Kawasan Konservasi Perairan Kepulauan Karimunjawa, Jawa Tengah" Tahun Anggaran 2012, merupakan kerjasama BP2KSI dengan P4KSI BALITBANG KP dengan Fakultas Perikanan dan Ilmu Kelautan Universitas Diponegoro Semarang. (2) Program Double Degree UNDIP-Jepang (BU-BPKLN) yang telah membiayai pendidikan Penulis selama melanjutkan pendidikan pada Program Studi Magister Ilmu Kelautan Universitas Diponegoro (3) Bapak Dr. Rudhi Pribadi, Sdr. Abdul Hadi, S.Kel., M.Si., Sdri. Wa Jali, S.Pi. M.Si dan semua Tim Peneliti yang telah membantu selama pelaksanaan penelitian. Akhirnya penulis berharap semoga makalah ini dapat bermanfaat dan memberikan khasanah pengetahuan khususnya dalam bidang konservasi sumberdaya ikan.

\section{DAFTAR PUSTAKA}

Adrim M, M. Djamali \& A.V. Toro. 1984. Komunitas ikan di daerah Mangrove Gugus Pulau Pari. Prosiding Seminar II EkosistemMangrove.Baturaden 3-5 Agustus 1982.p 183-197. 
Adrim, 2008. Bioecological aspects of Parrotfishes (Famili Scaridae). Journal. Vol. XXXIII. Nomor 1 :41-50. Oseana.Pusat Penelitian Oseanografi-LIPI.

BTN Karimunjawa.2010. Statistik Balai Taman nasional Karimunjawa. BTNKJ. Semarang

Chong V.C., A. Sesakumar, A. Leh \& R.D. Cruz. 1990. The Fish and prawn communities of a malaysian Coastal Mangrove system, with comparisons to adjacent Mud Flats and Inshore Waters. Estuarine, Coastal and Shelf Science 31: 703-722.

Djamali, A. 1995. Komunitas ikan di perairan sekitar Mangrove (Studi kasus di: Muara Sungai Berau, Kalimantan Timur; Cilacap, Jawa Tengah dan Teluk Bintuni, Irian Jaya). Prossiding Seminar V Ekosistem Mangrove, Jember 3-6 Agustus 1994: $160-167$.

Fischer, W. 1974.FAO Species Identification Sheets for Fishery Purposes.Volume I, II, III, IV. Italy: Fishery Resources Survey and Evaluation Service, Fishery Resources and Environment Division, FAO.

Genisa, A.S. 2006.Keanekaragaman fauna ikan di perairan mangrove Sungai Mahakam.Jurnal Oseanologi dan Limnologi di Indonesia 41: 39- 53.

Gunarto. 2004. Konservasi mangrove sebagai pendukung sumber daya hayati perikanan pantai. Jurnal Litbang Pertanian 23: 15-21.

Kementerian Lingkungan Hidup. 2004. Keputusan Menteri Negara Lingkungan Hidup Nomor: 51 Tahun 2004 tentang Baku Mutu Air Laut. Jakarta.

Kementerian Lingkungan Hidup. 2004. Keputusan Menteri Negara Lingkungan Hidup Nomor: 201 Tahun 2004 tentang Kriteria Baku dan Pedoman Penentuan Kerusakan Mangrove. Jakarta.

Kuiter, R, H., Takamasa, T. 2001. Pictorial Guide to : Indonesian Reef Fishes Part 2. Zoonetics. Australia.

Leiss and C. Ewart. 2000. Guide to identification to Order and Famili and Main characters of larvae of commercially important fish in the South East Asia region. The larvae of Indo-Pacific coastal fishes: an identification guide to marine fish larvae. Samut Prakan, Thailand: The Regional Training Workshop on Larval Fish Identification and Fish Early Life History Science Seaf. Seafdec/Td.

Matsuura KS, Sumandhiharga OK, Katsumi T. 2000. Field Guide To Lombok Island (Identification Guide to Marine Organisms in Seagrass Beds of Lombok Island, Indonesia). Tokyo: Ocean Research Intitute, University of Tokyo. 
McManus, J.W., R.I. Miclot \& V.T. Salagano. 1981. Coral and fish community stracture of Somrero Island, Batanganos, Philippines. Proc. Fourth int. Coral Reef Symp: 271-280.

Nurgayah. 2011. Komposisi dan struktur komunitas iktiofauna di Perairan Ekosistem Mangrove Pulau Lentera Kecamatan Kaledupa Selatan Kabupaten Wakatobi Sulawesi Tenggara. Jurnal Aqua Hayati, 7(3):197-206.

Pramudji. 2008. Mangrove di Indonesia dan upaya pengelolaannya. Ortasi Pengukuhan Profesor Riset Bidang Ekologi Laut. P2O-LIPI 31 hal.

Pribadi, $d k k$. 2013. Kajian komunitas ikan di perairan Kawasan Pulau Parang, Kepulauan Karimunjawa, Jepara. Jurnal Ilmu Kelautan. 18(1):43-52.

Rohmimohtarto, K. dan Juwana, S. 2001. Biota Laut: Ilmu Pengetahuan Tentang Biota Laut. Penerbit.Djambatan. Jakarta. $540 \mathrm{hlm}$.

SEAFDEC. 2007. Larval Fish : Identification Guide for the South China Sea and Gulf of Thailand. Seafdec.

Wahyudewantoro, G. 2009. Komposisi Jenis Ikan di Perairan Mangrove pada Beberapa Muara Sungai di Taman Nasional Ujung Kulon Pandeglang Banten.Jurnal Zoo Indonesia. 18(2): 89-98.

Wildlife Conservation Society (WCS). 2009. Laporan Teknis Monitoring Ekologi Taman Nasional Karimunjawa 2009.Laporan Monitoring fase 4. WCS Indonesia. Jakarta (tidak dipublikasikan) 